УДК 336.227

DOI: https://doi.org/10.37320/2415-3583/21.2

Глущенко Я.І.

кандидат економічних наук, доцент Національний технічний університет Украӥни «Київський політехнічний інститут імені Ігоря Сікорського» ORCID: https://orcid.org/0000-0003-1454-0369

Шенгер М.I. студентка Національний технічний університет Украйни «Київський політехнічний інститут імені Ігоря Сікорського» ORCID: https://orcid.org/0000-0002-8015-0492

Десна А.М. студентка Національний технічний університет України «Киїський політехнічний інститут імені Ігоря Сікорського» ORCID: https://orcid.org/0000-0002-3994-4821

\title{
СУТНІСНИЙ АНАЛІЗ ПОНЯТТЯ «ПОДАТКОВЕ ПЛАНУВАННЯ ТНК» В УМОВАХ ДІї ВЕРS
}

У статті проведено сутнісний аналіз понять «податкове планування», «корпоративне податкове планування», «агресивне податкове планування», наданих вітчизняними і зарубіжними науковиями. Проведене співставлення дозволило визначити тотожні та відмінні риси у досліджених трактуваннях. Обгрунтовано думку авторів щуодо недоцільності формулювання мети податкового планування, як мінімізація податкових зобов 'язань. Підкреслено увагу вітчизняних науковиів до взаємоузгодження інтересів держави і суб' єктів господарювання у процесі розробки моделей податкового планування на сучасному етапі розвитку економіки. Зазначено причини появи такого виду податкового планування, як агресивне. Визначено необхідність виокремлення та надано трактування терміну податкове планування транснаціональних корпорацій з урахуванням заходів проекту BEPS.

Ключові слова: податкове планування, ТНК, база оподаткування, агресивне податкове планування, конвергенція інтересів.

Постановка проблеми. Вивчення питань оподаткування цікавить людство майже з моменту застосування податків для формування бюджету держав. По мірі розвитку і вдосконалення систем оподаткування, платники податків розробляли заходи і методи оптимізації податкових зобов'язань. Серед яких одне із центральних місць належить податковому плануванню.

Аналіз останніх досліджень і публікацій. У сучасній вітчизняній і зарубіжній літературі присвячено багато праць проблематиці податкового планування. Слід відзначити вагомий вклад у розробку теоретикометодичних засад податкового планування таких науковців, як Оліховського В.Я. [1], Баранова С.О. [2], Брехова С.С., Коротуна В.І., Сушкової О.С., Новицької Н.В. [3], Корецької С.О. [4], Малікова В.В., Абрамової О.С. [5], Притуляка Н.М. [6], Супруненко С.А. [7], Чернякової Т.М., Хуснулліної Ю.І. [8], Щербини Ю. [9].

Останній час у науковій літературі все частіше обговорюються не тільки проблеми і перспективи податкового планування, його відмінності від «мінімізації» податкових платежів, а і його різновиди: корпоративне i індивідуальне, агресивне і неагресивне. Інтенсивність протікання глобалізаційних процесів, розробка та запровадження світових заходів боротьби з ухиленням від оподаткування обумовлюють актуальність дослідження такого поняття, як податкове планування ТНК в умовах BEPS.

Мета статті полягає у проведенні сутнісного аналізу понять «податкове планування», «корпоративне податкове планування» і надання визначення терміну «податкове планування ТНК» 3 урахуванням заходів проекту BEPS.

Виклад основного матеріалу. У наукових працях сьогодення(Оліховського В.Я., Баранова С.О., Брехова С.С., Коротуна B.I., Сушкової О.С., Новицької Н.В., Притуляка Н.М. та ін.), присвячених податковому плануванню, досліджуваний термін трактується, як «легальний шлях зменшення податкових зобов'язань», коли по суті платник податків обирає моделі своєї діяльності з урахуванням податкових преференцій окремим галузям чи регіонам (табл. 1). Семантично близький термін у своїх працях використовують Корецька С.О. [4], Чернякова Т.М., Хуснулліна Ю.І. - «мінімізація податків» [8]. Інший вітчизняний науковець Щербина Ю. використовує термін «оптимізація», але наголошуючи, при цьому, як і попередньо розглянутих працях, на не порушенні податкового законодавства [9]. На нашу думку, більш доцільно у трактуванні поняття «податкове планування» використовувати саме термін оптимізація податкових платежів. Бо, зменшення податкових зобов'язань не завжди у середньо- і довгостроковій перспективі може бути вигідно і самому суб'єкту господарювання. Так, наприклад, вітчизняні підприємці іноді обирають загальну систему оподаткування, або спрощену 3 групи зі сплатою 3\% і реєстрацією, як платник ПДВ, щоб не втрачати клієнтів і споживачів, які зацікавлені у формуванні податкового кредиту. 
Таблиця 1 - Визначення поняття «податкове планування» у літературних джерелах вітчизняних авторів

\begin{tabular}{|c|c|}
\hline Джерело інформації & Визначення понять \\
\hline $\begin{array}{l}\text { Оліховський В.Я. } \\
(2018, \text { с. } 46)\end{array}$ & $\begin{array}{l}\text { «...податкове планування... легальний шлях зменшення податкових зобов’язань, що передбачає } \\
\text { не лише обчислення сум окремих податків та загальної суми податкових платежів на плановий } \\
\text { період, а й можливість вибору між альтернативним використанням тих чи інших схем оподатку- } \\
\text { вання з метою оптимізації сум окремих податків та загальної суми податкових платежів у плановому } \\
\text { періоді». }\end{array}$ \\
\hline $\begin{array}{l}\text { Брехов С.С., } \\
\text { Коротун В.І., } \\
\text { Сушкова О.С., } \\
\text { Новицька Н.В. та ін. } \\
(2017, \text { с. } 36)\end{array}$ & $\begin{array}{l}\text { «Відповідно до чинного податкового законодавства податкове планування потрібно трактувати як } \\
\text { легальний шлях зменшення податкових зобов'язань, оснований на використанні можливостей, нада- } \\
\text { них податковим законодавством, шляхом коригування своєї діяльності та методів ведення обліку. } \\
\text { Під цим необхідно розуміти цілеспрямовану діяльність платника податків, орієнтовану на макси- } \\
\text { мальне використання всіх нюансів наявного податкового законодавства з метою зменшення податко- } \\
\text { вих платежів до бюджету» }\end{array}$ \\
\hline $\begin{array}{l}\text { Щербина Ю. } \\
\text { (2016, с. 99) }\end{array}$ & $\begin{array}{l}\text { Тодаткове планування - це спосіб оптимізації податкових виплат, який не вступає в суперечність із } \\
\text { инним законодавством та у майбутньому, як очікується, призведе до поступового зменшення рівня } \\
\text { даткового навантаження на сільськогосподарські підприємства». }\end{array}$ \\
\hline $\begin{array}{l}\text { Баранов С.О. } \\
(2015, \text { с. } 70)\end{array}$ & $\begin{array}{l}\text { «Податкове планування (tax planning) - легальний спосіб зменшення податкових зобов’язань, засно- } \\
\text { ваний на використанні можливостей, наданих податковим законодавством, шляхом розподілу плате- } \\
\text { жів виходячи з надходжень економічного суб’єкта з використанням бухгалтерського обліку». }\end{array}$ \\
\hline $\begin{array}{l}\text { Супруненко С.А. } \\
\text { (2013, с. 196) }\end{array}$ & $\begin{array}{l}\text { «Під податковим плануванням ми розуміємо сукупність інструментів, методів, прийомів, способів } \\
\text { і засобів інформаційно-аналітичного забезпечення, за допомогою яких державні органи та суб'єкти } \\
\text { господарювання реалізують на законодавчій основі податковий механізм і узгоджують повноваження } \\
\text { i функції в податковій сфері при постійних економіко-політичних змінах». }\end{array}$ \\
\hline $\begin{array}{l}\text { Маліков В.В., } \\
\text { Абрамова О.С. } \\
(2012, \text { с. } 17)\end{array}$ & $\begin{array}{l}\text { «У сучасних умовах недосконалої податкової системи України податкове планування має бути } \\
\text { невід’ємною частиною стратегії розвитку підприємства, а податкова стратегія - засобом зв’язку із } \\
\text { мінливим зовнішнім середовищем у сфері оподаткування та взаємодії підприємства та держави задля } \\
\text { забезпечення інтересів обох сторін». }\end{array}$ \\
\hline Корецька С.О. (2011) & $\begin{array}{l}\text { «Податкове планування - складова частина фінансово-господарської діяльності як фізичних, так і } \\
\text { юридичних осіб, у зв’язку з чим його можна поділити на індивідуальне (характерне як для сімей, так } \\
\text { i для некорпоративного сектора економіки) і на корпоративне. Завдання податкового планування - } \\
\text { максимізація доходу за рахунок мінімізації податків». }\end{array}$ \\
\hline $\begin{array}{l}\text { Притуляк Н.М. } \\
(2009, \text { с. } 245)\end{array}$ & $\begin{array}{l}\text { «Податкове планування полягає в тому, що воно є основою формування податкової політики під- } \\
\text { приємства та передбачає вибір між різними варіантами фінансово-господарської діяльності } \\
\text { найоптимальнішого, а також розміщення його активів з метою досягнення найнижчого рівня подат- } \\
\text { кових зобов’язань, які виникають при цьому». }\end{array}$ \\
\hline $\begin{array}{l}\text { Чернякова Т.М., } \\
\text { Хуснулліна Ю.І. } \\
(2008, \text { с. } 274)\end{array}$ & $\begin{array}{l}\text { ю фінансового планування..... На нашу думку метою податкового } \\
\text { a якого податкові платежі були б мінімальними». }\end{array}$ \\
\hline
\end{tabular}

Зарубіжні вчені також пов'язують податкове планування суб'єктів господарювання 3 вибором виду діяльності 3 урахуванням податкових стимулів. Так, Lingqi Xue [10] досліджуючи податкове планування китайських підприємств розглядає його у контексті податкових преференцій КНР: податкових пільг підприємствам, що залучені до реалізації національної стратегії омолодження країни та підтримки талантів; екологічним підприємствам, які використовують для виробництва та експлуатації відпрацьовані гази, стічні води та відходи. За твердженням автора, вибір зазначених видів діяльності дозволяє заощадити податкові витрати та максимізувати економічні вигоди [10, с. 2]. Про податкову економію мова йде і у праці Penno Mark C., яка присвячена моделям податкового планування [11, с. 2].

Слід зазначити, що в останні роки все частіше у працях вітчизняних вчених наголошується на необхідності конвергенції інтересів держави і суб'єктів господарювання у процесі податкового планування. Так, у визначенні поняття «податкове планування» Супруненко С.А. [7, с. 196] вказано на узгодженість повноважень і функції в податковій сфері держави i суб'єктів господарювання. На взаємодії підприємств і держави задля забезпечення інтересів обох сторін наголошено і у визначенні терміну «податкове планування» Малікова В.В. та Абрамової О.С. [5, с. 17].

Погоджуючись із думками Щербини Ю., Супруненко С.А., Малікова В.В., Абрамової О.С. наголошуємо, що у сучасних реаліях боротьби урядів держав і Організації економічного співробітництва та розвитку із розмиванням баз і ухиленням від оподаткування при визначенні поняття «податкове планування», обов'язково потрібно акцентувати увагу на узгодженні інтересів держави, як суб'єкта, що розробляє і реалізує податкову політику, і суб'єктів господарювання, ефективність діяльності яких, не в останню чергу, залежить від рівня податкового навантаження.

За суб'єктною складовою у науковій літературі податкове планування розподіляють на корпоративне й індивідуальне. Так, за думкою Магопець О.А. «корпоративне податкове планування одна 3 функцій управління фінансово-господарською діяльністю, яка полягає у встановленні передбачуваних параметрів майбутнього стану об'єкта, оптимальних способів і методів досягнення даного стану в умовах обмеженості ресурсів та при допустимому рівні податкового ризику» [12, с. 185]. 
У праці Непочатенко О.О., Бечко П.К. і Барабаш Л.В. корпоративне податкове планування, як і у вищенаведеному визначенні, також розглядається через призму управління, а саме управління фінансами і трактується, як «використання допустимих законом засобів, прийомів та способів для максимальної мінімізації своїх податкових зобов'язань» [13, с. 97-98].

Враховуючи мінливість зовнішнього економічного середовища, постійно зростаючу роль ТНК в міжнародній економіці, використання корпораціями особливостей податкового законодавства окремих країн світу для розмивання податкових баз, на нашу думку, доцільно виділити в окремий вид податкове планування транснаціональних корпорацій.

Саме розвиток зазначеного виду податкового планування, на нашу думку, обумовив необхідність виділення i розгляду таких його видів, як агресивне i неагресивне.

Так, за визначенням Сврокомісія агресивне податкове планування визначається, як «надмірне використання можливостей зниження податкового навантаження при використанні особливостей і невідповідності двох чи більше податкових систем» [14, с. 21]. У монографії вітчизняних вчених Брехова С.С., Коротуна В.I., Сушкової О.С., Новицької Н.В. та інших [3, с. 38], також підкреслюється, що агресивне податкове планування пов'язане 3 «прийняттям рішень у сфері оподаткування, які можуть призвести до наслідків, відмінних від закріплених податковим законодавством через його невизначеність або багатоваріантне трактування». Таким чином, може стверджувати, що зазначений вид податкового планування спрямований на мінімізація податкових зобов'язань і зменшення рівня податкового навантаження, i, по суті, не дозволяє взаємоузгодити інтереси держави і суб'єктів господарювання.

Враховуючи вищевикладене, пропонуємо під податковим планування ТНК в умовах BEPS розуміти процес розробки моделей діяльності при оптимальному рівні податкових зобов'язань і податкового навантаження корпорацій в межах діючого податкового законодавства окремих країн світу та норм міжнародного права, побудованого на конвергенції інтересів держави і компаній

Висновки. На підставі проведеного сутнісного аналізу понять «податкове планування», «корпоративне податкове планування», «агресивне податкове планування» та дослідження було запропоновано за суб'єктною ознакою виокремлювати податкове планування ТНК. Елементами наукової новизни є подальший розвиток понятійно-категоріального апарату податкового менеджменту шляхом уточнення терміну «податкове планування ТНК», у якому, на відміну від наявних, запропоновано ключовим принципом розробки моделей діяльності корпорацій у сучасних умовах визначати конвергенцію інтересів держав і компаній. У подальших дослідженнях буде розглянуто та охарактеризовано моделі поведінки транснаціональних корпорацій в умовах дії проекту BEPS.

\section{Список використаних джерел:}

1. Оліховський В.Я. Методи та інструменти податкового планування в системі менеджменту підприємства : дис. канд. екон. наук: 08.00.04. Львів, 2018. 270 с.

2. Баранов С. О. Ухилення від сплати податків як основний чинник тіньової економіки. Інвестиції: практика та досвід. 2016. № 12. С. 102-106. URL: http:// www.investplan.com.ua/pdf/12_2016/23.pdf (дата звернення: 15.12.2021).

3. Протидія агресивному податковому плануванню: світовий досвід та виклики для України : монографія / Брехов С.С., Коротун B.І., Сушкова О.Є., Новицька Н.В. та ін.; за заг. ред. С.С. Брехова та В.І. Коротуна. Київ : Алерта, 2017. 344 с.

4. Корецька С.О. Планування розвитку податкового потенціалу підприємств на основі комплексного підходу. Ефективна економіка. 2011. № 10. URL: http://www.economy.nayka.com.ua/?op=1\&z=722 (дата звернення: 15.12.2021).

5. Маліков В.В., Абрамова О.С. Розробка стратегії податкового планування на підприємстві. Проблеми і перспективи розвитку підприємництва. 2012. № 2. С. 13-17.

6. Супруненко С.А. Податкове планування як засіб гармонізації взаємовідносин держави та суб'єктів господарювання. Економічний аналіз : зб. наук. праць / Тернопільський національний економічний університет. 2013. Том 13. С. 194-200. ISSN 1993-0259.

7. Притуляк Н.М. До питання податкового планування на підприємстві. Збірник наукових праць Національного університету державної податкової служби України. 2009. № 1. С. 243-250.

8. Чернякова Т.М., Хуснулліна Ю.І. Роль податкового планування в управлінні податками на підприємстві. 3бірник наукових пращь КНТУ. 2008. № 14. С. 273-277. URL: http://dspace.kntu.kr.ua/jspui/bitstream/123456789/2382/1/49.pdf (дата звернення: 15.12.2021).

9. Щербина Ю. Необхідність податкового планування у сільськогосподарських підприємствах. Галицький економічний вісник. 2016. Т. 50. № 1. С. 98-104. URL: https://galicianvisnyk.tntu.edu.ua/pdf/50/90.pdf (дата звернення: 15.12.2021).

10. Lingqi Xue. Management and Research of Enterprise Tax Planning under the Background of Information Age. Journal of Physics: Conference Series. 1992 (2021). P. 1-6. URL: https://iopscience.iop.org/article/10.1088/1742-6596/1992/4/042017/pdf (дата звернення: 15.12.2021).

11. Penno Mark C. A Theory of the Tax Avoidance (Tax Planning) Continuum. July 9, 2021. P. 1-36. URL: https://papers.ssrn.com/ sol3/papers.cfm?abstract_id=3883570 (дата звернення: 15.12.2021).

12. Магопець О. А. Організація податкового планування в системі корпоративного податкового менеджменту. Наукові праиі Кіровоградського національного технічного університету. 2008. Вип. 14. С. 185-193. URL: http://dspace.kntu.kr.ua/jspui/ bitstream/123456789/2477/1/33.pdf (дата звернення: 15.12.2021).

13. Непочатенко О.О., Бечко П.К., Барабаш Л.В. Роль корпоративного податкового планування у діяльності суб'єктів господарювання. Збірник наукових праць Уманського національного університету садівництва. 2019. Вип. 94. Ч. 2: Економічні науки. С. 95-108.

14. Aggressive tax planning indicators. Final Report. European Commission. Taxation paper. 2017. № 71.189 p. URL: https://ec.europa.eu/taxation_customs/system/files/201803/taxation_papers_71_atp_pdf (дата звернення: 15.12.2021). 


\section{References:}

1. Olikhovskyi V. YA. (2018) Methods and tools of tax planning in management system of the enterprise: dissertation in order to obtain a scientific degree of Candidate of Economic Sciences: 08.00.04. Lviv. 270 p. (in Ukrainian)

2. Baranov S.O. (2019) Ukhylennia vid splaty podatkiv yak osnovnyi chynnyk tinyovoi ekonomiky [Tax Evasion as a Major Factor of the Shadow Economy]. Investytsii: praktyka ta dosvid, no. 12, pp. 102-106. Available at: http://www.investplan.com.ua/ pdf/12_2016/23.pdf (accessed 15 December 2021). (in Ukrainian)

3. Protydiia ahresyvnomu podatkovomu planuvanniu: svitovyi dosvid ta vyklyky dlia Ukrainy (2017). [Counteracting aggressive tax planning: world experience and challenges for Ukraine] / Brekhov S.S., Korotun V.I., Sushkova O.Ye., Novytska N.V. ta in.; za zah. red. S.S. Brekhova ta V.I. Korotuna. Kyiv: Alerta, 344 p. (in Ukrainian)

4. Koretska S.O. (2011) Planuvannia rozvytku podatkovoho potentsialu pidpryiemstv na osnovi kompleksnoho pidkhodu [Planning the Development of Tax Potential of Enterprises on the Basis of an Integrated Approach]. Efektyvna ekonomika, no. 10. Available at: http://www.economy.nayka.com.ua/?op=1\&z=722 (accessed 15 December 2021). (in Ukrainian)

5. Malikov V.V., Abramova O.S. (2012) Rozrobka stratehii podatkovoho planuvannia na pidpryiemstvi [Development of Tax Planning Strategy at the Enterprise]. Problemy i perspektyvy rozvytku pidpryiemnytstva, no. 2, pp. 13-17. (in Ukrainian)

6. Suprunenko S.A. (2013) Podatkove planuvannia yak zasib harmonizatsii vzaiemovidnosyn derzhavy ta subiektiv hospodariuvannia [Tax planning as a means of harmonisation of interrelationship between state and economic entities]. Ekonomichnyi analiz : zb. nauk. prats / Ternopilskyi natsionalnyi ekonomichnyi universytet, vol. 13, pp. 194-200. (in Ukrainian)

7. Prytuliak N.M. (2009) Do pytannia podatkovoho planuvannia na pidpryiemstvi [On the Issue of Tax Planning at the Enterprise]. Zbirnyk naukovykh prats Natsionalnoho universytetu derzhavnoi podatkovoi sluzhby Ukrainy, no. 1, pp. 243-250. (in Ukrainian).

8. Cherniakova, T. M., Khusnullina, Yu. I. (2008) Rol podatkovoho planuvannia v upravlinni podatkamy na pidpryiemstvi [The Role of Tax Planning in the Management of Taxes in the Enterprise]. Zbirnyk naukovykh prats KNTU, no. 14, pp. 273-277. Available at: http://dspace.kntu.kr.ua/jspui/bitstream/123456789/2382/1/49.pdf (accessed 15 December 2021). (in Ukrainian)

9. Scherbyna Y. (2016) Neobkhidnist podatkovoho planuvannia u silskohospodarskykh pidpryiemstvakh [The need for tax planning in agrarian enterprises]. Halytskyi ekonomichnyi visnyk, vol. 50, no. 1, pp. 98-104. Available at: https://galicianvisnyk.tntu.edu.ua/ pdf/50/90.pdf (accessed 15 December 2021). (in Ukrainian)

10. Lingqi Xue (2021) Management and Research of Enterprise Tax Planning under the Background of Information Age. Journal of Physics: Conference Series, no. 1992, pp. 1-6. Available at: https://iopscience.iop.org/article/10.1088/1742-6596/1992/4/042017/pdf (accessed 15 December 2021).

11. Penno Mark C. (2021) A Theory of the Tax Avoidance (Tax Planning) Continuum. July 9, pp. 1-36. Available at: https://papers.ssrn.com/sol3/papers.cfm?abstract_id=3883570 (accessed 15 December 2021).

12. Mahopets O.A. (2008) Orhanizatsiia podatkovoho planuvannia v systemi korporatyvnoho podatkovoho menedzhmentu [Organization of tax planning in the system of corporate tax management]. Naukovi pratsi Kirovohradskoho natsionalnoho tekhnichnoho universytetu, vol. 14, pp. 185-193. Available at: http://dspace.kntu.kr.ua/jspui/bitstream/123456789/2477/1/33.pdf (accessed 15 December 2021). (in Ukrainian)

13. Nepochatenko O.O., Bechko P.K., Barabash L.V. (2019) Rol korporatyvnoho podatkovoho planuvannia u diialnosti subiektiv hospodariuvannia [The role of corporate tax planning in the activities of economic entities]. Zbirnyk naukovykh prats Umanskoho natsionalnoho universytetu sadivnytstva, vol. 94, no. 2: Ekonomichni nauky, pp. 95-108. (in Ukrainian)

14. Aggressive tax planning indicators. Final Report. European Commission. Taxation paper. 2017, no. 71, 189 p. Available at: https://ec.europa.eu/taxation_customs/system/files/201803/taxation_papers_71_atp_.pdf(accessed 15 December 2021).

Hlushchenko Yaroslava, Shenger Miroslava, Desna Anastasiia National Technical University of Ukraine «Igor Sikorsky Kyiv Polytechnic Institute»

\section{ANALYSIS OF THE ESSENCE OF DEFINITIONS OF «TAX PLANNING» OF TNCS IN CONDITIONS OF BEPS}

The article critically analyzes the definitions of domestic and foreign scholars of «tax planning», "corporate tax planning», and "aggressive tax planning». The study allowed the authors to identify similarities and distinctive features of these definitions. Researchers have note that in these definitions the purpose of the tax planning point out to reduce, minimize and optimize tax liabilities. At the same time, almost all researchers emphasize that tax planning should take place within the current legislation of the countries, and, as a rule, aimed at using existing tax preferences for industries and regions of countries. The article describes the types of tax preferences granted to Chinese companies and offered for consideration in the process of tax planning. The authors substantiated the interpretation of tax planning from the point of optimizing tax payments and tax burden in the medium and long term, taking the peculiarities of the domestic tax system. The article notes that domestic scholars emphasize the importance of reconciling the interests of the state and business entities in the process of developing models of tax planning at the present stage of economic development of country. The authors note that according to the subjective component of tax planning divided into corporate and individual. In addition, corporate tax planning often considered from the point of view of corporate financial management. The authors substantiate the need to apply the definition tax planning of TNCs using modern trends in the world economy. It is determined that one of the reasons for distinguishing the type of aggressive tax planning is the activities of multinational corporations, aimed at taking into using the mismatches and loopholes in the international tax framework to reduce their overall tax burden. The authors propose a definition of tax planning of multinational corporations, taking into using the measures of the BEPS project. This definition, in contrast to the existing ones, proposes to develop models of corporate activities in modern conditions using the principle of convergence of interests of states and companies.

Key words: tax planning, TNCs, tax base, aggressive tax planning, convergence of interests.

JEL classification: $\mathrm{H} 21, \mathrm{H} 26, \mathrm{H} 71$ 